\title{
THE BASIS OF THE STUDY OF THE AGE OF THE HOLOCENE DILUVIUM ON LOESS AREAS OF POLISH HIGHLANDS
}

\author{
ANDRZEJ BLUSZCZ ${ }^{1}$, GRZEGORZ J. PORĘBA ${ }^{1}$ and ZBIGNIEW ŚNIESZKO ${ }^{2}$ \\ ${ }^{I}$ Department of Radioisotopes, Institute of Physics, Silesian University of Technology, \\ Krzywoustego 2, 44-100 Gliwice, Poland \\ ${ }^{2}$ Faculty of Earth Sciences, Silesian University, \\ Będzińska 60, 41-200 Sosnowiec, Poland
}

Received 15 June 2007

Accepted 13 July 2007

\begin{abstract}
Large part of slope sediments (pediment) which are the effect of water induced soil erosion in the loess areas of Polish Uplands, has a close relationship with pre-historical, historical and "present" agricultural activity. The sediments accumulated in different periods are often separated by fossil soils. These soils are correlated with the periods of relinquishment of agricultural land use in a given area. A precise dating of the cycles of fossil soil formation is practically impossible. Therefore it is important to gain a possibility to establish the age of sediments between old fossil soils corresponding with the phases of soil erosion. The organic material in the floor or roof of deposits permitting a ${ }^{14} \mathrm{C}$ dating is very seldom. This is why attempts were made to use the OSL method to date mineral parts of slope sediments. In connection with pedological and sedimentological methods, the OSL method makes it possible to give some information about the age of pre-historical and historical phases of intensive soil erosion. In order to date sediments accumulated during the last 50 years, the method based on measurement of ${ }^{137} \mathrm{Cs}$ isotope in products of soil erosion is used. This paper shows some examples of the application of ${ }^{14} \mathrm{C}$, OSL and ${ }^{137} \mathrm{Cs}$ methods in some selected research sites. In each case there is a discussion of limitations of the methods used.
\end{abstract}

Keywords: OSL dating, ${ }^{137} \mathrm{Cs}$ method, ${ }^{14} \mathrm{C}$ dating, loess

\section{INTRODUCTION}

The precise establishing of the age of origin of rocks plays an important role in the modelling of environment dynamics in the past. Basing on chronological methods used in geology, it is possible to join some events which occur in remote places into one cause-result system. Often during such investigations an incorrect assumption is made that all data obtained for different materials and by different methods are equally reliable. This procedure is used also for investigation of water erosion sediment. Each change on the slope due to ploughing causes accelerated soil erosion on the slope and sediment accumulation at the foothill, within mid-slope flat areas and in valley floors. A reliable dating of slope sediments and alluvia is essential in estimation of agricultural impact on the environment in different stages of development of soil cultivating cultures (Starkel, 1998).

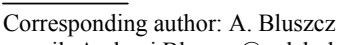
e-mail: Andrzej.Bluszcz@polsl.pl
Holocene sediments connected with soil erosion may be dated by isotope methods as well as OSL method. Some comments about the usefulness of methods based on the ${ }^{137} \mathrm{Cs}$ and ${ }^{14} \mathrm{C}$ isotopes and OSL method are presented below. The study area and the localization of the sampling points are given in Fig. 1. In this figure, the loess areas in the South of Poland are also marked.

\section{DATING OF MODERN PROLUVIUM- DILUVIUM SEDIMENTS BY THE ANALYSIS OF ${ }^{137}$ CS ISOTOPE CONTENT}

The ${ }^{137} \mathrm{Cs}$ is an anthropogenic radioisotope which was introduced into the atmosphere mainly during nuclear weapon tests. The fallout occurred mainly in the 1950's and 1960's. After this period, the fallout of caesium has been systematically decreasesing.

After the deposition on the soil surface, caesium is strongly adsorbed on soil particles, especially on colloidal fractions. The transport of caesium into deeper soil layers 


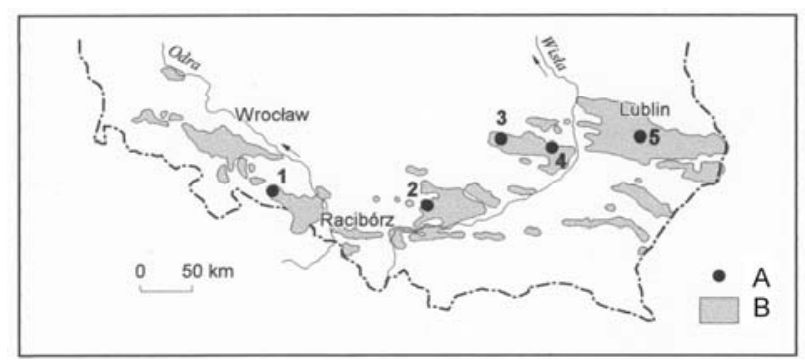

Fig. 1. The localization of the study areas described in the text. A - study areas, B - loess areas; 1 - Biała, 2 - Biedrzykowice, 3- Czyżówka, 4 - Sierakowice, 5 - Jędrzejówka.

results mainly from agricultural processes in cultivated soils and from bioturbation or migration with fine mineral grains and soil colloids for natural soils (Zygmunt et al., 1998; Poręba, 2006). Due to a short period when caesium is present in the environment the magnitude of vertical migration of caesium in the soil profile is negligible (Bluszcz and Śnieszko, 2000; Poręba et al., 2003). In a ploughed chernozem soil, within the horizons of humus accumulation, a clear boundary is visible between Ap horizon enriched in caesium and the underlying A horizon (Fig. 2). Below this boundary there is no ${ }^{137} \mathrm{Cs}$ or its activity is close to zero (Fig. 3).

Due to denudation processes during the last 50 years ${ }^{137} \mathrm{Cs}$ was mobilized on slopes together with eroded soil particles. After accumulation it remained adsorbed on fine grain slope sediments. The measurements of caesium in sediments have been made since the mid 1960's. The first loessial sediment profile was dated by this method in the experimental field in Huldenberg (Mucher, 1985). A 6 meter thick sediment column was correlated with the last 900 years but the top $54 \mathrm{~cm}$ was correlated with the last 30 years. A similar thickness of diluvium marked by caesium method was found in Poland in Kłodzko Basin and in Lubelska Upland (Bluszcz and Śnieszko, 2000; Zgłobicki, 2001). In the profile of slope sediments in Biała located in Głubczycki Plateau a $50 \mathrm{~cm}$ thick sediment is clearly marked by anthropogenic caesium (Poręba and Bluszcz, 2003).

The assessment of sedimentation rates of slope sediments during the last 50 years in the loess areas in Poland may influence the interpretation of Holocene profiles of these sediments. These studies represent an interesting material for discussion especially when the agricultural fields in the loess areas predominate. The studies based on the caesium method show an incomparably higher rate of sedimentation of the eroded soil during the last 50 years than in the earlier phases of Holocene relief development. This results from both deep ploughing and a large proportion of root plants in the crops. The caesium method may asses the intensity of the soil erosion processes.

\section{DATING OF OLDER SLOPE SEDIMENTS BY THE ${ }^{14} \mathrm{C}$ METHOD}

The evaluation of age of older Holocene slope sediments and alluvia is feasible with the application of the ${ }^{14} \mathrm{C}$ method. The Holocene diluvia and alluvia often con-

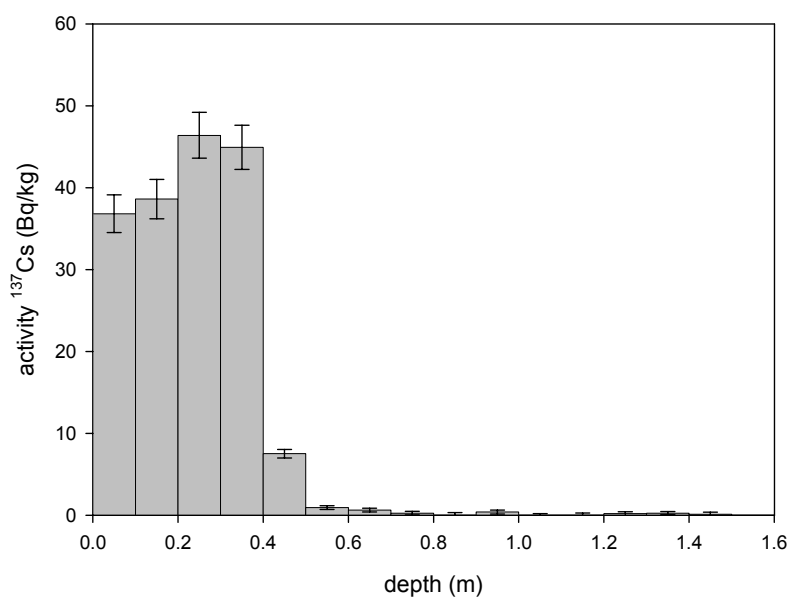

Fig. 2. The vertical distribution of ${ }^{137} \mathrm{Cs}$ in soil from Biała.

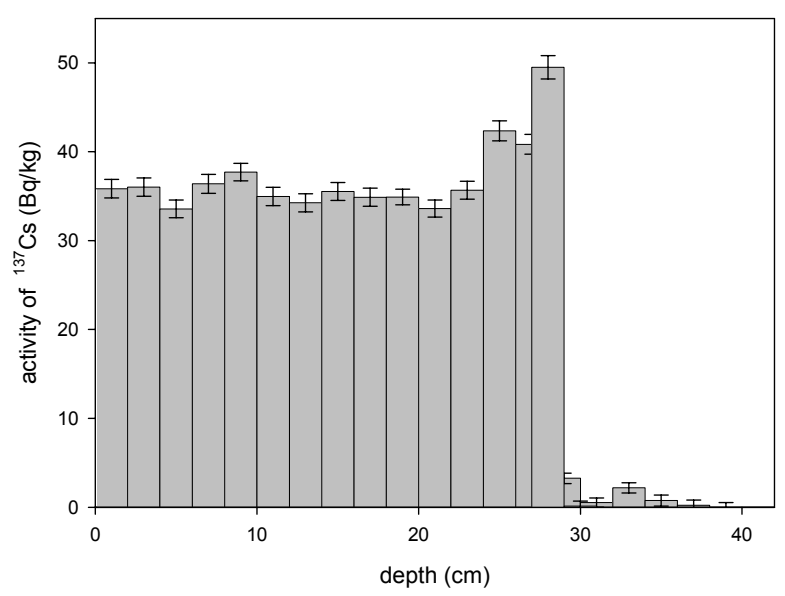

Fig. 3. The vertical distribution of ${ }^{137} \mathrm{Cs}$ in soil from Odonów. Plough depth is $27 \mathrm{~cm}$ here.

tain organic matter on a secondary bed (the matter transferred from the slope) that is mixed with organic matter formed during post sedimentation humification processes in situ. In the Miechowska Upland intensive rainstorms caused massive redeposition and a significant increase of the organic carbon in deposits at the toe of the slope, from $0.33 \%$ to $2.22 \%$. It was mainly humus, washed out from the soil on the slope (Dwucet and Śnieszko, 1997).

If older and deeper parts of soils are eroded, which is typical for linear erosion, the older organic carbon from the deeper humus layer is mixed with the modern sediments. The presence of redeposited humus in the modern deposit falsifies the dating result when the ${ }^{14} \mathrm{C}$ method is used to date it. By analogy, radiocarbon dating of such deposits is questionable.

However, the ${ }^{14} \mathrm{C}$ method can be used to date the slope deposit indirectly if it is bracketed within fossil soils. Indirect dating of the slope sediment or the flood alluvium consists of determination, by using the ${ }^{14} \mathrm{C}$ method, of the age of overlying and underlying organic horizons. The result is still questionable, or severely biased, if the dating is performed on humus layers of fossil soils. The bias comes not from the method itself but rather from the nature of the dated object. The humus 
layer forms during several thousand year time and is continuously being enriched with "fresh" carbon (having higher content of ${ }^{14} \mathrm{C}$ isotope), and zoopedoturbation processes mix it with the "older" carbon, depleted in ${ }^{14} \mathrm{C}$ isotope. As a result, a radiocarbon date of the humus horizon is always younger than the beginning of soil formation and older than the youngest organic substances in the soil (Pazdur, 1982). Often, however, during the interpretation of the age of deposits dividing the fossil soils it is incorrectly assumed that the radiocarbon dates of organic horizons are directly related to the age of dated material. Dating of slope sediments from Jędrzejówka, Sieradowice and Czyżówka valley shows wide chronostratygrapic gaps in the Holocene profiles at the contact of fossil soils and slope sediments (Fig. 4). These gaps considerably influence the interpretation of the chronostratigraphic position of slope sediment.

\section{Jędrzejówka (Śnieszko, 1991; 1995)}

In the floor of proluvial-deluvial deposits of the thickness exceeding $9 \mathrm{~m}$, organic deposits dated to $7860 \pm 140$ BP (9050-8350 cal BP, 95.4\% confidence int., Gd-2314) (Bronk and Ramsey, 1995; 2001; Reimer et al. 2004). This horizon contains scattered oak trunks dated to $870 \pm 50$ BP (920-690 cal BP, 95.4\% confidence int., Gd2315). The trunks' ages give, therefore, the age of the lower part of these deposits. A genetic interpretation is necessary to connect closely the mentioned sedimentary series with the date of the trunks (Śnieszko, 1991). Thus, dating of proluvial deposits must be supported with a thorough genetic analysis of deposits.

\section{Sieradowice (Śnieszko, 1995)}

A soil horizon developed on the deluvial deposits aggradated onto a sinter was dated by the ${ }^{14} \mathrm{C}$ method at $4870 \pm 70$ BP (5750-5450 cal BP, 93.6\% confidence int., Gd-1572). Above the soil horizon there are proluvialdeluvial deposits up to $3.5 \mathrm{~m}$ thick. The presence of the $12^{\text {th }}$ century cultural horizon was determined within the boundary between a ceiling of the soil and the floor of proluvial-deluvial deposits. Stratigraphic gap between the soil and deluvial deposits accounts to 4 thousand years at least.

\section{Czyżówka valley}

The investigations of Kosmowska-Suffczyńska (1983) in the Czyżówka valley (near Ożarów Sandomierski) showed that $6 \mathrm{~m}$ thick layer of deluvial-proluvial deposits with $14^{\text {th }}$ and $15^{\text {th }}$ century ceramic directly overlies the soil whose ceiling was dated by the ${ }^{14} \mathrm{C}$ method at $5140 \pm 120$ BP (6200-5600 cal BP, 95.4 confidence int.). Similarly as it is in Świeradowice, a stratigraphic gap occurs here accounting to about 4.2 thousand years.

The given examples clearly show serious limitations of interpretation of ages of slope deposits overlying fossil soils in cases when only humus horizons are dated.

Moreover, the examples mentioned above show that, even in favourable conditions, the analyses of sediment genesis and other sources of historical knowledge are necessary to arrive at a correct conclusion.

For some reasons, however, humus horizons of fossil soils have been dated using the radiocarbon method. If the resulting dates would have been used to date the deposits dividing fossil soils reliably, it should be remembered that the smallest error in age interpretation is obtained if humus horizons developed in short periods (several dozen years or so), and under the condition that there was no humus on secondary deposit. The longer is the time of development of fossil soil dividing diluvia, the lesser is the cognitive value of radiocarbon dates. Satisfactory results of ${ }^{14} \mathrm{C}$ dating are obtained for diluvia and colluvia containing pieces of wood in the floor layer in situ. This was the way colluvia formed during heavy rainstorm in Jędrzejówka were dated $(870 \pm 50$ BP /920690 cal BP, 95.4 confidence int., Gd-2315/ - Śnieszko, 1991). The sites that fulfil these conditions are rare, however. An extensive discussion about the dating of fossil soil by the ${ }^{14} \mathrm{C}$ method was done by Pazdur (1982).

\section{DATING OF SLOPE DEPOSITS BY THE OSL METHOD}

In the light of considerable limitations connected with the application of radiocarbon method for dating deposits of Holocene soil erosion, the efficiency of dating these deposits using the optically stimulated luminescence (OSL) method should be tested.

The OSL dating method is based on the dosimetric properties of quartz grains extracted from the dated sedi-

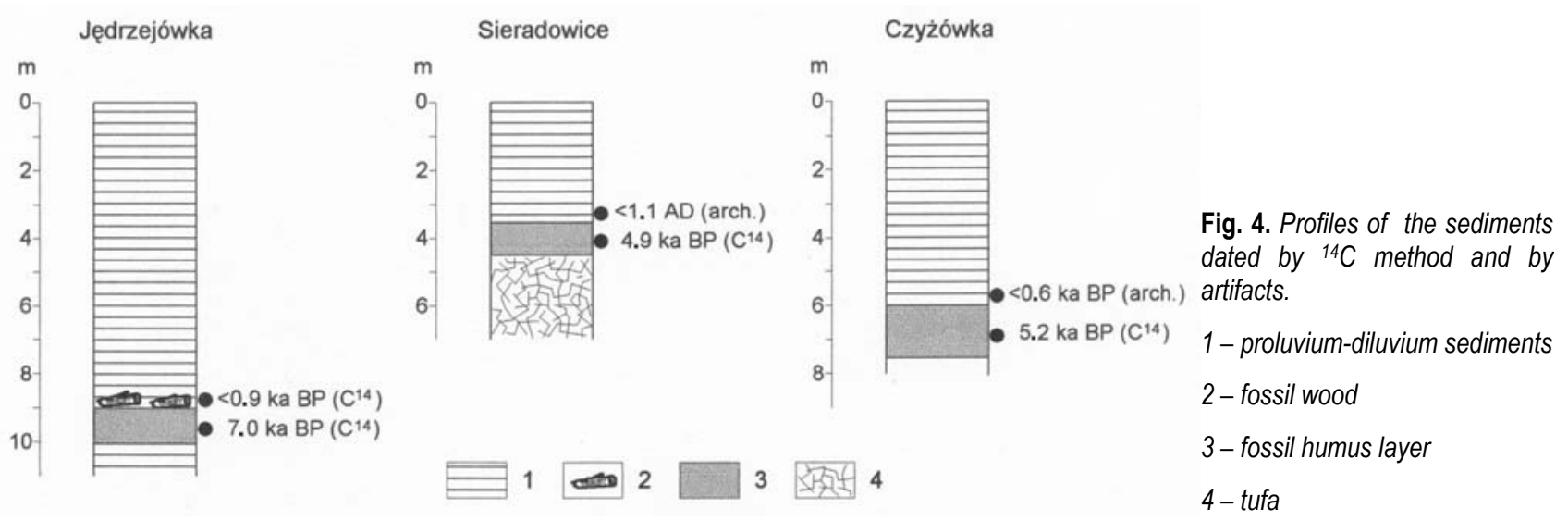


ment. The amount of luminescence stimulated optically is related directly to the dose of ionising radiation absorbed by the grains since the last exposure to sunlight. The ionising radiation dose rate depends on the natural radioactivity of the sediment and may be assumed constant over time. Thus, assuming that grains were indeed exposed to sunlight, or bleached, shortly before or during the deposition, the absorbed dose measures the age of the sediment.

The absorbed dose is measured on small portions of coarse quartz grains, including from one to several dozen luminescence emitting grains. If the grains were not properly bleached, that is the exposure of all grains was too short to effectively bleach them, or different grains were bleached to different residual levels, the absorbed doses measured by OSL vary from one quartz grains portion to another. The variation of assessed dose is commonly attributed to the variation of the proportion of well bleached grains in a particular portion.

When slope deposits derived from loess are dated by the OSL method the bleaching by exposure to sunlight could occur in one of the three phases of sediment history.

\section{- Phase 1}

This is a phase of eolian accumulation of loess. The age of primary accumulation is older than $10 \mathrm{ka}$. The exposure to sunlight stops when grains are covered with a solid layer (epipedon). After that some grains may be transferred between different layers as a result of mixing caused by mesofauna, e.g. mole mounds.

\section{- Phase 2}

The soil is converted into the cultivated field. Ploughing causes mixing of soil to a certain depth and some grains are exposed to sunlight. The longer is the period of cultivation the larger proportion of grains in loess ceiling becomes bleached, but still some epipedon grains remain unexposed.

- Phase 3

Water erosion. Both grains from the surface (surface wash) and grains from deeper layers of the loess deposit (rillwash) are transported. Some of these grains may be bleached again, while others still have dose absorbed in phases 1 and 2 .

Washed sediments become deposited at base of the slope and covered by successive diluvial-proluvial deposits.

Therefore slope deposits contain grains of different depositional age. The deposit contains grains that have not been bleached since the moment of loess accumulation, grains rejuvenated during mixing by soil fauna, grains rejuvenated by soil cultivation, and grains that date the washing process. The results obtained by OSL dating of certain portions of extracted grains may thus vary from portion to portion reflecting the variation of ages of different phases.

\section{Dating of modern slope deposits in Zloty Stok}

Some important suggestions to interpretation of the results of dating by the OSL method are provided by investigating the results of dating of slope sediments carried down a young slope cover containing ${ }^{137}$ Cs. Fig. 5 presents a histogram of OSL ages obtained on small

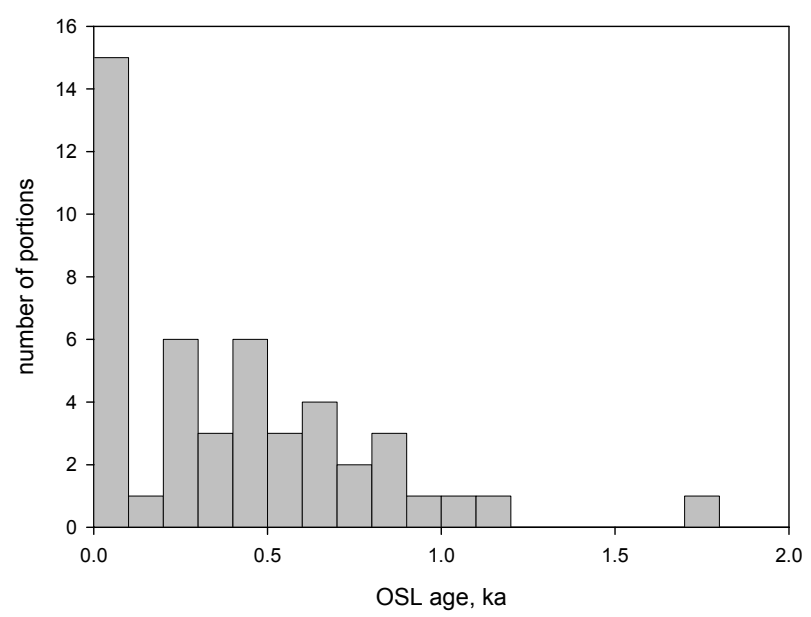

Fig. 5. The distribution of OSL ages measured for a sample from ${ }^{137} \mathrm{Cs}$ containing layer of slope deposits in Złoty Stok.

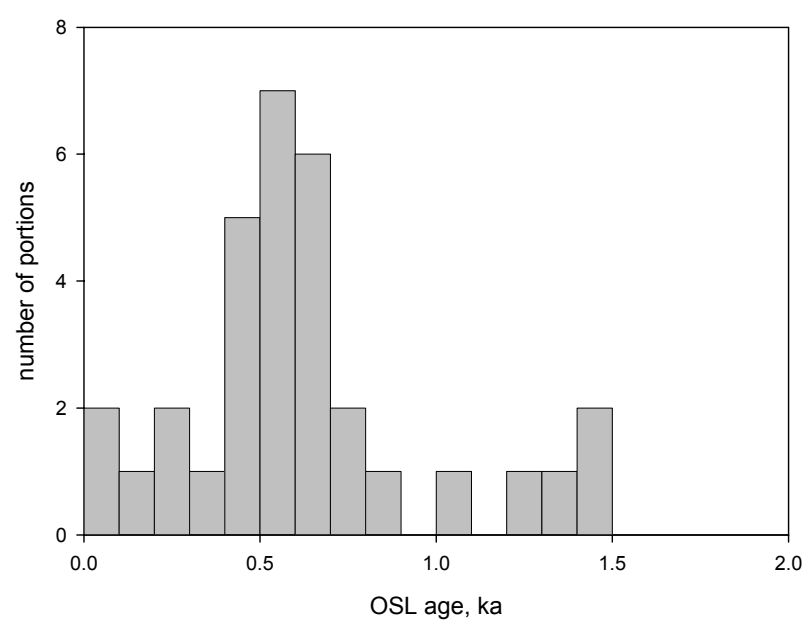

Fig. 6. The distribution of OSL ages measured for a sample from a layer below the range of ${ }^{137} \mathrm{Cs}$ occurrence in slope deposits in Złoty Stok.

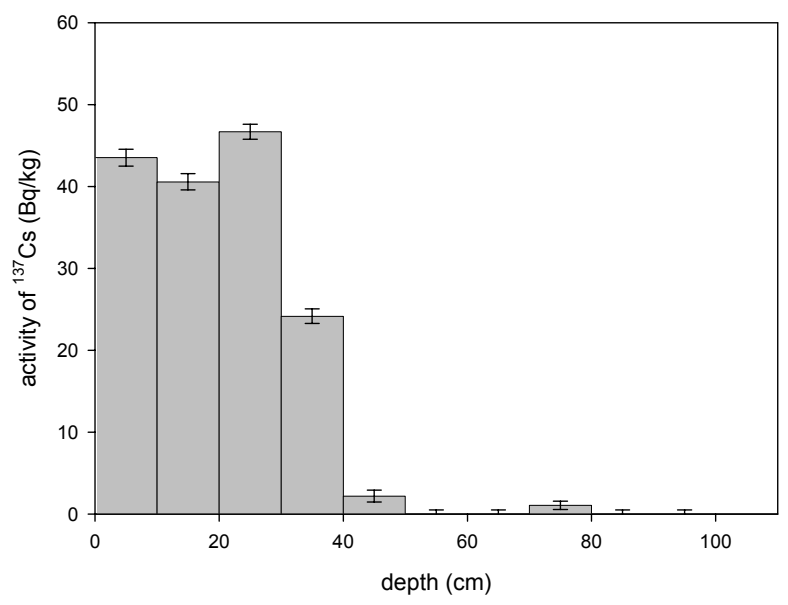

Fig. 7. The vertical distribution of ${ }^{137} \mathrm{Cs}$ in soil from Złoty Stok.

quartz grain extracts from the $50 \mathrm{~cm}$ thick layer accumulated during the last 50 years, and Fig. 6 presents a similar histogram for older deposits below the caesium con- 
taining layer (The vertical distribution of the ${ }^{137} \mathrm{Cs}$ in soil is presented in Fig. 7). For both samples the range of OSL ages spans between 0 and about $1.5 \mathrm{ka}$. For the sample dated by caesium to be younger than 50 years, 16 portions give the age approximate to a real one and 32 portions gave older ages. For a sample older than 50 years 18 portions give the age from 300 to 600 years, 6 portions give the age younger than 300 years and 8 portions give the age older than 600 years. Dating by the OSL method using small portions of grains yields a distribution of results reflecting the distribution of depositional ages in the sediment. The situation found in the presented example excludes a precise dating of sedimentation but may be interpreted in the light of geological knowledge about processes of sedimentation of slope deposits. Despite the lack of precision, the method may be used to approximate dating of older deposits.

\section{Dating of slope deposits in Biedrzykowice}

The profile in Biedrzykowice was described by Śnieszko (1995). Material for OSL dating was sampled from deposits between the soil dated by radiocarbon method to late Vistulian / early Holocene boundary (date from $10130 \pm 210$ to $8600 \pm 230 \mathrm{BP} / 12610-11200$ cal BP, 95.4\% confidence int., Gd-872; 10230-9090 cal BP, $95.4 \%$ confidence int., Gd-870/) and the young soil of undefined age. The deposits form a $87 \mathrm{~cm}$ thick layer with massive structure, suggesting a large role of pedoturbation and synsedimentation processes in the formation of the deposit. Material for dating was sampled from depths $315 \mathrm{~cm}, 295 \mathrm{~cm}$ and $228 \mathrm{~cm}$, below present surface. The distribution of OSL ages measured for a sample from Biedrzykowice is shown on Fig. 8.

Age of "reliable" portions:

Bd $1-228 \mathrm{~cm}$ - younger than $0.9 \mathrm{ka}$ OSL

Bd $2-295 \mathrm{~cm}$ - younger than $1.2 \mathrm{ka}$ OSL

Bd 3 - $315 \mathrm{~cm}$ - younger than 1.9 ka OSL

In the samples $\mathrm{Bd} 1$ and $\mathrm{Bd} 3$ a portion was measured in which grains "burdened" by age predominate, which corresponds to the accumulation of roof layers of loess (12.1 - $12.6 \mathrm{ka}$ OSL).

The presence of unbleached grains in the deposits

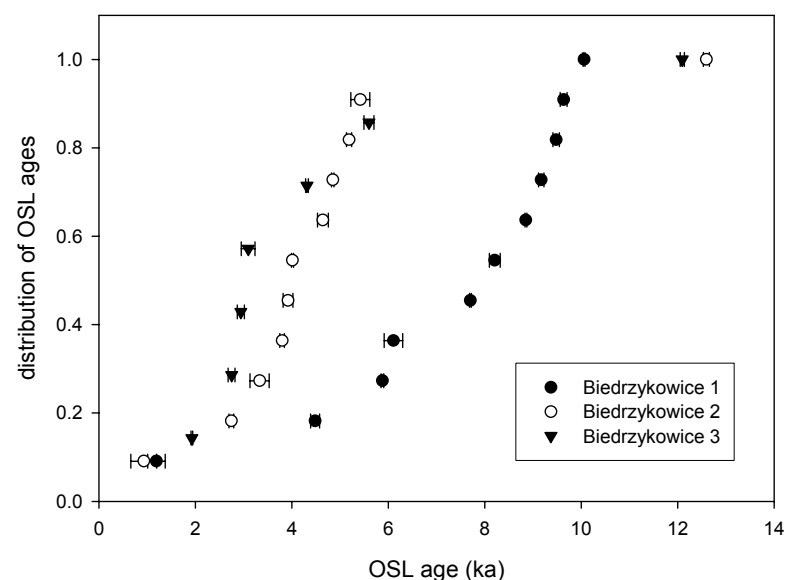

Fig. 8. The distribution of OSL ages measured for samples from slope deposits in Biedrzykowice. suggests the occurrence of linear erosion during intensive precipitation and activation of old loess grains. Part of these grains was not bleached.

\section{Dating of slope deposits in Biała}

The soil profile in Biała is similar to the soil profile in Biedrzykowice.

Also here there is a soil profile where in the floor a late Vistulian / early Holocene soil is well developed. It is overlaid by a diluvium. A successive soil developed on the diluvium is again overlaid by a younger diluvium. Both in the diluvium between soils, and in the humus horizon of the younger soil, charcoals occur. In the diluvium Quercus charcoals, and in the humus horizon $\mathrm{Ul}$ mus charcoals have been identified. The diluvium contains also inserts of coarse grain material.

The samples were taken from the depth of 155 and $185 \mathrm{~cm}$. The OSL age of single portions indicates a large time gap between both samples. The distribution of OSL ages measured for a sample from Biała is shown in Fig. 9.

The age of "reliable" portions:

Biała $1-155 \mathrm{~cm}$ - younger than $1.5 \mathrm{ka} \mathrm{BP}$

Biała $2-185 \mathrm{~cm}$ - younger than $3.1 \mathrm{ka} \mathrm{BP}$

The oldest dates Biała $1-3.1 \mathrm{ka}$ BP, Biała $2-5.0 \mathrm{ka}$ BP show that the proportion of material from linear washing is here smaller than in Biedrzychowice. Rapid flows occurred here, however, which is evidenced by a coarse grain material in the slope cover. Possibly one of these rapid flows caused erosive gap between samples Biała 1 and Biała 2.

Dating of deposits in Biała leads to a conclusion, that the diluvium-proluvium cover which developed here includes the period with two important phases of colonization. The floor part of profile Biała 2 began to develop during the Lusatian colonization in this area. The prehistorical pits assigned to Lusatian culture were found close to a brick-yard not more than $200 \mathrm{~m}$ from the investigated soil profile. In its older part, the fragments of the burial-ground of Lusatian culture were found (Gedl, 1962).

Just $30 \mathrm{~cm}$ above the sample Biała 2 there are depos-

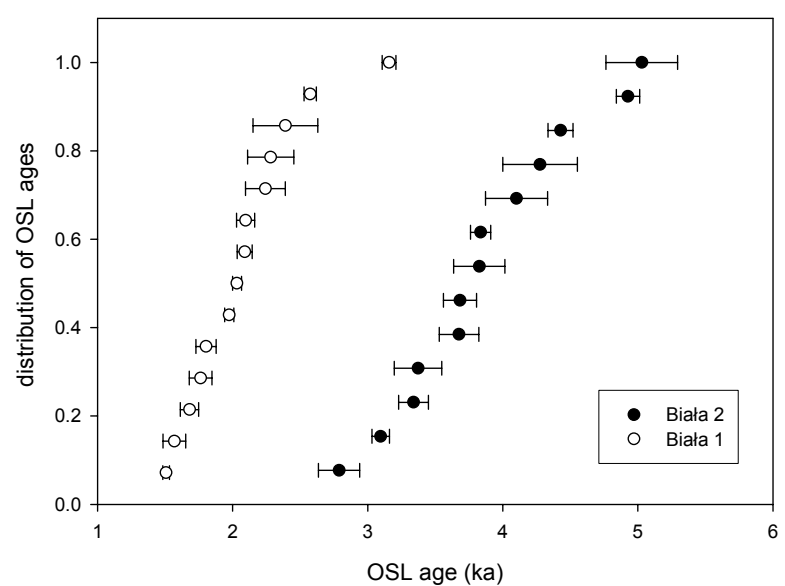

Fig. 9. The distribution of OSL ages measured for samples from slope deposits in Biała. 
its which could originate in the Middle Ages. These deposits may be correlated with the phase of the earliest colonization connected with the origin of Biała settlement. The oldest written information about this colony comes from the $13^{\text {th }}$ century (Borek, 1988)

Such a long cycle recorded in the deposits of small thickness shows that there is an erosive gap formed probably during ploughing activity in the valley bottom. Otherwise, a clear horizon of humus accumulation would have developed in the roof of the older diluvium.

\section{CONCLUSIONS}

To obtain correct evaluation of the age of deluvialproluvial deposits in Holocene profiles in loess areas, results of radiocarbon dating of organic substance present in the soil between these sediments are not sufficient enough. The OSL dating of these sediments is also biased. Presenting the distribution of ages of individual portions is more correct than presenting a single OSL age for a given sample. In each case results of dating by the ${ }^{14} \mathrm{C}$ and OSL methods should be interpreted in the light of archaeological evidence and historical facts available for the investigated area. The results of sedimentological and palaeopedological investigations should also be taken into account as they influence the evaluation of the rate of processes leading to development of a given geological profile.

\section{REFERENCES}

Bluszcz A and Śnieszko Z, 2000. Zawartość izotopu ${ }^{137}$ Cs we współczesnych osadach powodziowych i deluwiach Kotliny Kłodzkiej (The concentration of ${ }^{137} \mathrm{Cs}$ in modern flooding sediments an diluvium in Kłodzko Valley). In: Ostafczuk S, ed., Dynamiczna ocena $i$ prognoza geologicznych zagrożeń wywołanych powodzia - na przykładzie Nysy Kłodzkiej, Górnej Soły i Górnego Sanu-Solinki (The dynamic evaluation and prognosis of the geological danger induced by flood - on the example of Nysa Kłodzka river, Górna Soła river and Górny San-Solinka river). Kraków, PAN: 63-68 (in Polish).

Borek H, 1988. Górny Ślask $w$ świetle nazw miejscowych (The Upper Silesia in the light of locals names). Opole, Instytut Śląski: 41 pp. (in Polish).

Bronk Ramsey C, 1995. Radiocarbon Calibration and Analysis of Stratigraphy: The OxCal Program Radiocarbon 37(2): 425-430.

Bronk Ramsey C, 2001. Development of the radiocarbon calibration program OxCal, Radiocarbon 43 (2A): 355-363.

Dwucet K and Śnieszko Z, 1997. Zmiany fizykochemiczne cech lessu i gleb nalessowych po redepozycji spowodowanej gwałtowną ulewą
(The changing of teh physical an dchemical properties of the loess and loessive soil after redeposition due to rainstorm). In: Starkel L, ed., Rola gwałtownych ulew w ewolucji rzeźby Wyżyny Miechowskiej (na przykładzie ulewy w dniu 15 września 1995 roku) (The influence of the rainstorms on the evolution of the Miechowska Uppland). Kraków, Dokumentacja Geograficzna 8: 76-86.

Gedl M, 1962. Kultura łużycka na Górnym Śląsku (The Lusatian culture on the Upper Silesia). Wrocław-Warszawa-Kraków, Ossolineum: 317 pp. (in Polish).

Kosmowska-Suffczyńska D, 1983. Origin of the youngest fill revealing human activity; an example of the Czyżówka valley (Sandomierz Upland). Geographia Polonica 45: 19-34.

Mucher HJ, 1985. Aspects of loess and loess-derived slope deposits: an experimental and micromorphological approach. Nederlandse Geografische Studies 23: 267 pp.

Pazdur MF, 1982. Badanie dokładności datowania metodą ${ }^{14} \mathrm{C}$ późnopleistoceńskich i holoceńskich osadów organicznych (A study of the accuracy of radiocarbon dating of holocene and late plejstocene organic sediment). Zeszyty Naukowe Politechniki Ślaskiej 741, Seria Matematyka-Fizyka 41: 81 pp. (in Polish).

Poręba G, Bluszcz A and Śnieszko Z, 2003. Concentration and vertical distribution of ${ }^{137} \mathrm{Cs}$ in agricultural and undisturbed soils from Chechło and Czarnocin areas. Geochronometria 22: 67-72.

Poręba G and Bluszcz A, 2003: Zastosowanie metod Cs-137 i OSL do datowania gleb i osadów (The using Cs-137 and OSL methods to dating soils and sediments). In: Waga JM and Kocel K, eds., Człowiek w Środowisku Przyrodniczym - Zapis Działalności (Human in the natural environment - the record of the activity). Sosnowiec, Uniwersytet Śląski: 184-188 (in Polish)

Poręba G, 2006: Caesium-137 as a soil erosion tracer: a review. Geochronometria 25 : 37-46.

Reimer PJ, Baillie MGL, Bard E, Bayliss A, Beck JW, Bertrand C, Blackwell PG, Buck CE, Burr G, Cutler KB, Damon PE, Edwards RL, Fairbanks RG, Friedrich M, Guilderson TP, Hughen KA, Kromer B, McCormac FG, Manning S, Bronk Ramsey C, Reimer RW, Remmele S. Southon JR, Stuiver M, Talamo S, Taylor FW, van der Plicht $\mathbf{J}$ and Weyhenmeyer CE, 2004. IntCal04 terrestrial radiocarbon age calibration, 0-26 cal kyr BP. Radiocarbon 46: 1029-1058.

Starkel L, 1998. Funkcja powodzi w środowisku przyrodniczym dorzecza górnej Wisły (The function of the flood in the environment of Vistula river). In: Starkel L and Grela J, eds., Powódź w dorzeczu górnej Wisty w lipcu 1997 roku (The flood in the upper part of the Vistula river in July 1997). Konferencja Naukowa PAN Kraków 7-9 maja 1998 r: 9-20 (in Polish).

Śnieszko Z, 1991. Reflection of extreme events in evolution of dry valleys in loess Roztocze Upland. In: Jersak J, ed., Less i osady dolinne. Prace Uniwersytetu Śląskiego 1107: 119-129.

Śnieszko Z, 1995. Ewolucja obszarów lessowychWyżyn Polskich w czasie ostatnich 15000 lat (The loess cover ewolution during last 15,000 years in Polish Upplands): 5-122. Katowice.

Zgłobicki W, 2001. Dynamika wspólczesnych procesów denudacyjnych w pótnocno-zachodniej części Wyżyny Lubelskiej (The dynamic of modern denudation processes in north-west part of the Lubelska Highland). Lublin, Uniwersytet Marii Curie-Skłodowskiej: 159 pp.

Zygmunt J, Chibowski S and Klimowicz Z, 1998. The effect of sorption properties of soil minerals on the vertical migration rate of caesium in soil. Journal of Radioanalytical and Nuclear Chemistry 231(1-2): 57-62, DOI 10.1007/BF02388005. 